\title{
COVID-19 vaccination may cause FDG uptake beyond axillary area
}

Vincent Fleury ${ }^{1 *}$, Bruno Maucherat ${ }^{1}$, Daniela Rusu ${ }^{1}$, Frédéric Dumont ${ }^{2}$ and Caroline Rousseau ${ }^{1,3,4}$

\author{
* Correspondence: vfleury245@ \\ gmail.com \\ ${ }^{1}$ Department of Nuclear Medicine, \\ ICO Gauducheau Cancer Center, \\ Boulevard Monod, 44805 \\ Saint-Herblain Cedex ${ }_{\text {"France }}$ \\ Full list of author information is \\ available at the end of the article
}

\begin{abstract}
Background: The vaccination immune response may induce false-positive ${ }^{18} \mathrm{~F}-\mathrm{FDG}$ PET/CT uptake.

Case presentation: An extended supraclavicular lymph nodal activation after coronavirus disease 2019 (COVID-19) vaccination revealed on ${ }^{18} \mathrm{~F}$-FDG PET/CT mimics a Virchow nodule in a patient with medical history of well-differentiated appendicular adenocarcinoma.

Conclusion: This case highlights a nodal activation beyond axillary area and the importance of documenting vaccination history at the time of scanning to avoid false-positive results.

Keywords: FDG PET/CT, COVID-19, Vaccine
\end{abstract}

\section{Background}

Development of vaccines to prevent COVID-19 is a hope to prevent transmission or reduce the severity of infection. However, vaccination could be a potential source of false-positive results in ${ }^{18}$ F-FDG PET/CT (Katal et al. 2021).

\section{Case presentation}

We present the case of a 64-year-old female with well-differentiated appendicular adenocarcinoma associated with peritoneal carcinosis initially treated by surgery and chemotherapy benefited from a ${ }^{18} \mathrm{~F}$-FDG PET/CT to investigate a peritoneal nodule (Fig. 1). This peritoneal nodule (arrow) visualized on the axial (a) view of CT image showed no increased FDG uptake on the axial (b) PET/CT fused image. The MIP (c) and axial (D) PET/CT fused images detected an intense hypermetabolism on the left axillary lymph nodes up to the left supraclavicular area. The patient revealed she had received the first of dose Pfizer BNT162b2mRNA vaccine against COVID-19 on the left shoulder intramuscular 4 days before FDG examination. In order to exclude a Virchow nodule due to her digestive cancer history, we performed a cervical echography with supraclavicular node cytological biopsy sample. Echography (E) showed a 14-mmlong axis normal lymph node with its central hilum. Cytological analysis revealed activated lymphoid cells without tumor cells.

\section{SpringerOpen}

(c) The Author(s). 2021 Open Access This article is licensed under a Creative Commons Attribution 4.0 International License, which permits use, sharing, adaptation, distribution and reproduction in any medium or format, as long as you give appropriate credit to the original author(s) and the source, provide a link to the Creative Commons licence, and indicate if changes were made. The images or other third party material in this article are included in the article's Creative Commons licence, unless indicated otherwise in a credit line to the material. If material is not included in the article's Creative Commons licence and your intended use is not permitted by statutory regulation or exceeds the permitted use, you will need to obtain permission directly from the copyright holder. To view a copy of this licence, visit http://creativecommons.org/licenses/by/4.0/. 

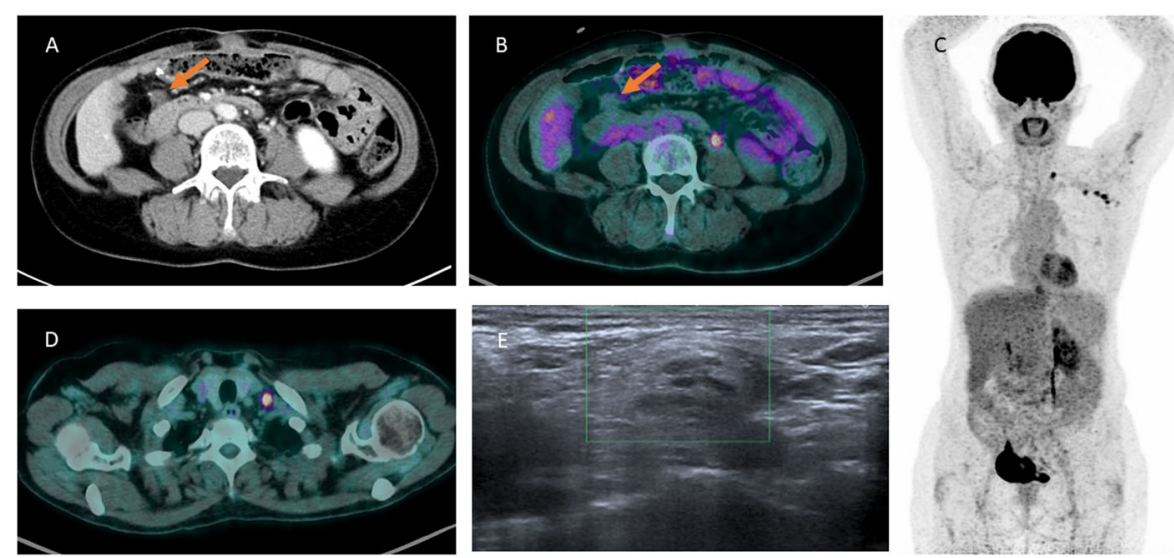

Fig. $1 C T$ scan showed a peritoneal nodule (arrow in a) with no increased uptake on fused ${ }^{18} \mathrm{~F}-\mathrm{FDG}$ PET/CT images (arrow in b). MIP (c) and fused ${ }^{18}$ F-FDG PET/CT (d) showed with increased uptake on the left axillary lymph nodes up to the left supraclavicular area. Echography (e) showed a normal supraclavicular lymph node

\section{Discussion}

Several previous reports have demonstrated axillary lymph nodal activation on ${ }^{18} \mathrm{~F}$ FDG PET/CT following influenza and COVID-19 vaccination (Burger et al. 2011; Shirone et al. 2012; Eifer et al. 2021; Nawwar et al. 2021). This case revealed an atypical extended supraclavicular activation. In the context of the COVID-19 pandemic and large vaccination programs, questionnaires including date and location of the vaccination can help to avoid false-positive lymph node interpretation with the risk of a therapeutic choice impact offered to the patient. In patients with solid tumor like breast cancer or melanoma, the vaccination should be performed in the contralateral arm to limit misinterpretations. Otherwise, it would be advisable to respect a time interval to define between the vaccination and ${ }^{18} \mathrm{~F}$-FDG PET/CT scan.

\section{Conclusion}

Nuclear physicians should be careful when cancers staging and re-staging. This is especially important for patients with breast cancer having been vaccinated on the homolateral upper limb, digestive cancer patients vaccinated on the left side, or with lung or head and neck carcinoma.

Acknowledgements

Not applicable

\section{Authors' contributions}

Conception and design: VF; BM; DR; FD; CR. Acquisition of data, analysis and interpretation of data: VF; BM; DR; FD; CR. Drafting the article and final approval of the revised manuscript: VF; BM; DR; FD; CR. All authors read and approved the final manuscript.

Funding

No funding

Availability of data and materials

Not applicable

\section{Declarations}

Ethics approval and consent to participate

As the FDG-PET/CT was part of a routinely performed clinical examination, no ethics approval was needed. 
Consent for publication

For this case report, the patient has consented to the submission.

Competing interests

The authors declare that they have no conflicts of interest or competing interests.

\section{Author details}

${ }^{1}$ Department of Nuclear Medicine, ICO Gauducheau Cancer Center, Boulevard Monod, 44805 Saint-Herblain Cedex "

France. ${ }^{2}$ Department of Surgical Oncology, ICO Gauducheau Cancer Center, Saint-Herblain, France. ${ }^{3} \mathrm{CNRS}$, Inserm, CRCI NA, Nantes, France. ${ }^{4}$ Nantes University, Nantes, France.

Received: 11 April 2021 Accepted: 10 May 2021

Published online: 01 June 2021

\section{References}

Burger IA, Husmann L, Hany TF, Schmid DT, Schaefer NG (2011) Incidence and intensity of F-18 FDG uptake after vaccination with H1N1 vaccine. Clin Nucl Med. 36(10):848-853. https://doi.org/10.1097/RLU.0b013e3182177322

Eifer M, Eshet Y (2021) Imaging of COVID-19 vaccination at FDG PET/CT. Radiology. 28:210030

Katal S, Pouraryan A, Gholamrezanezhad A (2021) COVID-19 vaccine is here: practical considerations for clinical imaging applications. Clin Imaging. 76:38-41. https://doi.org/10.1016/j.clinimag.2021.01.023

Nawwar AA, Searle J, Hagan I, Lyburn ID (2021) COVID-19 vaccination induced axillary nodal uptake on [18F]FDG PET/CT. Eur J Nucl Med Mol Imaging. 26:1-2

Shirone N, Shinkai T, Yamane T, Uto F, Yoshimura H, Tamai H, Imai T, Inoue M, Kitano S, Kichikawa K, Hasegawa M (2012 Apr) Axillary lymph node accumulation on FDG-PET/CT after influenza vaccination. Ann Nucl Med. 26(3):248-252. https://doi. org/10.1007/s12149-011-0568-x

\section{Publisher's Note}

Springer Nature remains neutral with regard to jurisdictional claims in published maps and institutional affiliations.

\section{Submit your manuscript to a SpringerOpen ${ }^{\circ}$ journal and benefit from:}

- Convenient online submission

- Rigorous peer review

- Open access: articles freely available online

- High visibility within the field

- Retaining the copyright to your article 